Powers, 'Introduction: On Relatives, Relations, and Relationships', in Dyani White Hawk: Speaking to Relatives, ed. Jennifer Doyle, exh. cat. (Kansas City, MO: Kemper Museum of Contemporary Art, 202I), 8.

3 Carmen Hermo, 'Dyani White Hawk: Accumulating Collective Power', in Doyle, Dyani White Hawk, I9.

4 Hermo, 'Dyani White Hawk', 2 I.

This is an Open Access journal distributed under the terms of the Creative Commons Attribution License (CC-BY) 4.0 https://creativecommons.org/licenses /by/4.O/, which permits unrestricted use, distribution, and reproduction in any medium, provided the original author and source are credited.

Articles (C) 2022 the contributors

HTTPS://DOI.ORG/10.14324/111.444.2396-9008.065

Andy Warhol, Tate Modern, London, 12 March-I5 November 2020. Catalogue: Eds. Gregor Muir and Yilmaz Dziewior (London: Tate Publishing, 2020), 244 pages, hardback, ISBN I8497667II, f40.00; paperback, ISBN I849766703, £25.00.

Louis Shankar

Curators Gregor Muir and Yilmaz Dziewior explain the thrust of their recent Andy Warhol exhibition at Tate Modern thus: 'This humanistic re-visioning explores his background as a child of an immigrant family, his ideas about death and religion, and his queer perspective, revealing an artist who both succeeded and failed in equal measure, and whose work marked a period of cultural transformation that still resonates today'. It is a sympathetic approach, although one that perhaps aspired for too much within a medium-sized survey show. Just one of the three frames of analysis would have provided better focus. Curatorial concerns of inclusion and exclusion always seem to come to the fore in a Warhol exhibition: there is so much to choose from, where does one draw the line?

There seemed to me a great irony in staging an exhibition dedicated to Andy Warhol, a notorious hypochondriac, in the midst of a global pandemic. 'Warhol was a hypochondriac for whom health and aesthetics were inextricably linked,' writes Brian Dillon, 'an artist who confronted the truth of the body as fearlessly as he did its fantasies'. ${ }^{2}$ And this was a show thoroughly dedicated to the artist himself - Andrew Warhola, the man beneath the wig - an attempt at revelation through the examination of overlooked and sidelined works.

The earliest works on display, from the collection of Paul Warhola, Andy's brother, are intriguing tempera and oil paintings. Surreal and eerie, they are not unlike mythic early works by Rothko and Pollock. Warhol's pared-back line drawings from the I950s, produced while he was working as a commercial illustrator, are wonderfully simple, elegant, and utterly camp. Male nudes or sensitive portraits of unidentified ephebes, the viewer's gaze is drawn to a crotch. Andy Warhol: Love, Sex, and Desire: Drawings 1950-1962, a coffee table book dedicated to these works, was also published in 2020. The beautifully sensual works are reproduced with intimate materiality and fidelity, and yet there is something very un-Warhol about them.

It was precisely this campness that Warhol soon purged from his later work. In order to become commercially successful, he had to refashion himself as an 'asexual dandy'. ${ }^{3}$ Much of this exhibition was part of a wider project - begun in academic circles in I996 and now filtering into the mainstream 
- to re-queer Warhol. ${ }^{4}$ Blake Gopnik's meticulous biography, Warhol: A Life as Art (2020), is a notable contribution in this vein. There is so much research on Warhol, with an entire industry dedicated to his work and legacy, and such a glut quickly becomes either overwhelming or tiresome. Gopnik presents an original and multifaceted portrait of the artist, while Love, Sex, and Desire gives a more sensitive, sidelong perspective of an uncertain young draughtsman. There are endless, multiple Warhols, each one like a screen-print, subtly different from the last.

Inevitably, the usual celebrity portraits appear, but elsewhere we have a lone butt piece - bearing the presumably tonguein-cheek title Torso (I977) - and one of his oxidation works (1978), also known as 'piss paintings', in urine and metallic paint on canvas. There are other esoteric works - Hammer and Sickle (1976) and Camouflage (I986) - alongside stalwarts such as Electric Chairs (I97I). But much of this exhibition's strength lay in peripheral content and ephemeral documentation, whether screenings of rarely shown video works, like Sleep (1963), or an extended exploration of Interview magazine. There's an incredible photograph of Warhol's mother in a taxi heading to Columbus Hospital: she clutches a newspaper with the headline 'Actress Shoots Andy Warhol'. Richard Avedon's photo portrait of Warhol's scarred torso (I969) - freed from its permanent surgical corset - is heart-breaking and painful. It seemed ironic that such a potent artwork, possibly the most powerful there, was of rather than by Warhol. But its purpose is vital: we are reminded of Warhol's humanity, his fragility.

The room dedicated to his series Ladies and Gentlemen (I975) was a revelation.
Commissioned by Italian art dealer Luciano Anselmino, Warhol made hundreds of paintings - ranging from the intimate to the monumental - depicting fourteen anonymous Black and Latinx drag queens and trans women (several have since been identified, but many remain unknown). The inclusion of Marsha P. Johnson, a pioneer within the queer liberation movement, has drawn increased attention to this series of works. Warhol had a long creative relationship with drag - from his I950s drawn drag portraits to his self-portrait polaroids in drag - and yet the source of this fascination remains enigmatic.

Potentially the most illuminating contribution, the installation's recreation of the mid-I960s Exploding Plastic Inevitable, was disappointingly precluded by COVIDI9 regulations on social distancing. A video evoked rather than replicated the EPI, a series of pseudo-Happenings held at the Factory in I966 and I967, which also spawned a film and a magazine. 'The show managed to fascinate and alienate its audience,' noted the curators, with Lou Reed describing the EPI as 'a show by and for freaks'. I left wanting more - perhaps next time.

The exhibition closed with Sixty Last Suppers (1986), a serial screen print derived from Leonardo's Last Supper. A meditation on mortality and legacy, this series was one of his last. Upon his return from its first exhibition in Milan, he immediately, albeit reluctantly, checked into a Manhattan hospital, where he died. It's an unusual, provocative note to end on: we're left pondering Warhol's beliefs, his death, and his lasting legacy.

I Gregor Muir and Yilmaz Dziewior, eds., Andy Warhol, exh. cat. (London: Tate Publishing, 2020), I. 2 Brian Dillon, Tormented Hope: Nine Hypochondriac Lives (London: Penguin, 2010), 236-37. 
3 Gavin Butt, Between You And Me: Queer Disclosures in the New York Art World, 1948-1963 (Durham, N.C.: Duke University Press, 2005), I I6-I8.

4 One such work of this kind is Jennifer Doyle, Jonathan Flatley, and José Esteban Muñoz, eds., Pop Out: Queer Warhol (Durham, N.C.: Duke University Press, I996).

This is an Open Access journal distributed under the terms of the Creative Commons Attribution License (CC-BY) 4.0 https://creativecommons.org/licenses /by/4.0/, which permits unrestricted use, distribution, and reproduction in any medium, provided the original author and source are credited.

Articles (C) 2022 the contributors

HTTPS://DOI.ORG/10.14324/111.444.2396-9008.066

\section{Daniel Heller-Roazen, Absentees: On Variously Missing Persons, Princeton University Press, Princeton, 202I, 320 pages, hardback, ISBN 978I942130475, f28.00.}

\section{Archie Squire}

In the age of indelible digital traces, the case of the 'absentee' may appear at once faded and extraordinarily vivid. 'Regrammed' appeals for missing persons; divisive 'cancel' cultures; and respects paid to deceased influencers via their final social media posts: each of these virtual phenomena reproduces distinct 'nonpersons' of the kinds set forth by Princeton Comparative Literature Professor Daniel Heller-Roazen in his most recent book, Absentees. By way of three typologies, Heller-Roazen explores literary figurations of the absent(ed) or missing. His examples range from Jonathan Swift's Gulliver's Travels (I726) to Franz Kafka's unpublished texts. He also attends with admirable precision to legal, social, ritual and theological practices, and in so doing opens his work to the possibility of other overlapping spheres, not least that of art history.

As the preface to Absentees makes clear, Heller-Roazen is interested in the 'nonperson' not as the negation or contrary of the person, but rather in the same sense as the nonstarter is still a starter, or the nonentity an entity. "This "nonperson" names the depletion of the notion to which it is bound,' he writes. ${ }^{1}$ The prefix non-reads perhaps as 'nevertheless'. The nonperson thus remains a person, only one for whom the very status of personhood does not remain fully intact or wholly concrete. For HellerRoazen, the nonperson is also manifold: nonpersons possess many forms and make themselves known and/or unknown through a multiplicity of apparitions both positive and negative.

In 'Part One: Vanishings,' Heller-Roazen navigates the undulating terrain of civil law and its wide-ranging treatment of vanished persons, troubled always by the doubt, in the words of the Roman jurists, of "where [s] he is and whether [s] he is' [ubi sit et an sit]. He demonstrates that across cultures and millennia, the law has sought to stipulate the abstract continuation of personhood for designated periods and under specific conditions, despite the lack of a present body.

'Part Two: Lessenings,' is concerned with an apparently opposite configuration. Contrary to the space carved out to protect and hold the place of the disappeared, HellerRoazen highlights the civil diminishment of present persons - their recreation as nonpersons, as variously 'cancelled'. Departing from the Roman term capitis deminutio ['decrease of the head'], which delimited (non)persons whose statuses were lessened, their citizenship reduced, or liberty altogether extinguished, Heller-Roazen 